\title{
A 10-Year-Old Girl's Overcoming the Negative Mother Complex and Its Relationship to Ego Development
}

\author{
Meera Kowen*
}

\begin{abstract}
$<$ Abstract $>$
This case study is of the sandplay process of a young girl whose ego development was delayed predominantly, it seems, because of negative mother archetypal energy expressed by the personal mother. The client is an elementary school-aged girl caught in the negative mother archetype, particularly in its devouring quality which was a manifestation of the mother's over-protectiveness; thus development of ego consciousness was impeded, as was a balanced relationship between ego and Self. The mother suffered from severe chronic depression and anxiety, and the father from panic disorder. As sandplay therapy progressed, client gradually began to engage in her everyday outer life and function normally, and the mother increasingly became less overprotective and more containing and accepting. As is evidenced in this case, sandplay therapy provided an environment which enabled the reconstitution of client's problematic primal relationship, constellation of the Self so that she developed a sense of self-worth and competency, and the reconstruction of her damaged ego-Self axis.
\end{abstract}

Keywords : sandplay therapy, relationship, ego development, Self, mother archetype

\footnotetext{
* Department of Child Welfare at Graduate School of Namseoul University
} Chief, Reborn Psychology Counselling Center (kowen0808@naver.com) 
Journal of Symbols \& Sandplay Therapy, Vol.8 No.1.

\section{Introduction}

The mother archetype bestows a nurturing function to the mother to take care of the child. It is also a predisposition or potential that provides the basis for psychological development of mankind as well as the formation and maintenance of society and culture. All archetypes have polarities, or opposites; so does the mother archetype. The image of the mother archetype can be light, benevolent, nurturing, and protective. At the same time it can be dark, evil, devouring, and destructive. Not only the mother archetype but also the personal mother is a combination of these opposites. All mothers have their individual characteristics, and a person's or several persons' experience with the same mother may be similar or different. Such a mother image is an arrangement of archetypes contained in our psyche, and becomes conscious through dreams, arts, sandplay therapy, and so on (Jang, 2017).

Eric Neumann theorizes the state of pre-ego consciousness as the uroborus. This is the stage of the primal Self which contains a germ or potential for development of the ego; the ego develops from this primal Self (Edinger, 1972). This process is equivalent to the child's Self becoming separated from the primal mother-child unity and entering into the phase of ego development. When the ego separates from the Self, typically an axis is formed between the two. The development of a healthy ego requires positive mother archetypal energy, which is characterized by containment, protection, nurturing, and acceptance in order to maximize development of one's potential (Neumann, 1973). When the negative mother archetype or another negative environmental factor causes early relational trauma, the self-care system will not function effectively in the outer world (Kalsched, 2013).

This case study is of the sandplay process of a young girl whose ego development was delayed predominantly, it seems, because of negative mother archetypal energy expressed by the personal mother. The process contains the theme of relationship trauma that occurred during the early attachment stage and also the negative aspect of the mother archetype in a symbolic sense. The client, "Jina", is an elementary school-aged girl caught in the negative mother archetype, particularly in its devouring quality which was a manifestation of the mother's over-protectiveness; thus development of ego consciousness was impeded, as was a balanced relationship between ego and Self. Her limitations manifested as a serious peer-relationship 
problem and maladjustment to the school environment. Kalsched (2013) defines the self-care system as a defensive mechanism at the archetypal level that develops prior to the development of ego defenses. When there is an early relationship trauma, the developmental process is interrupted in its adaptation to the outer world by developing a tendency to be abusive and aggressive, as a result protecting regressed aspects that are hidden. Play related to creative expression, such as sandplay therapy, has the potential to alleviate and heal trauma. Kalsched(2013) argues that healing and transformation can only occur, however, when they become the focal point of the relationship between the therapist and Jina, a factor possible within the free and protected space of sandplay therapy.

This paper aims to observe the client's sandplay process from the perspective of analytical psychology as she overcomes "bad breasts or anti-libidinal ego"(Woodman, 1990) in other words, the negative mother archetype that impedes the child from fulfilling the ego's potential for development of consciousness and attainment of a healthy ego status.

\section{Case Overview}

\section{Client information and the reason for receiving therapy}

At the time of therapy, Jina was 10-years-old, a fourth grade student in elementary school. Since advancing into the third grade, she had experienced difficulties in getting along with her peers and often fought with them, verbally and by scratching, especially when they threatened her, and pinched her. After visiting a pediatric psychiatrist and receiving psychological and intellectual tests, she was recommended by her doctor to receive psychological therapy

\section{Jina's characteristics and her main problems}

Jina was a thin girl of medium height with long hair and upturned, monolid eyes. Overall she looked like an average schoolgirl at her age. She frequently stared about, only 
Journal of Symbols \& Sandplay Therapy, Vol.8 No.1.

intermittently making eye contact. With a sulky face, she often mumbled to herself, "So annoying" or "What the heck."

Jina's mother complained that after entering the third grade, Jina often fought with her schoolmates and also struggled academically, as well as walking around the hallway during class time. What further concerned the mother was that Jina recently started to speak about her imaginary friends and talked to herself as if she was hallucinating. The mother reported that it saddened her to watch Jina being alone, unable to get along with her schoolmates, and she had begun to hate other children who were unfriendly to Jina. The mother was also worried that her child would not be able to keep up academically in the next school year as Jina was unable to concentrate in class. The mother worked in the general administrations office at Jina's school. She always got hung up on how Jina did at school, constantly snooping around Jina's classroom, to the extent that it interfered with her performance at work.

Psychological testing showed that the mother also suffered from severe chronic depression and anxiety, and the father from panic disorder. The mother also received treatment and counseling at the hospital where Jina had received testing at the time of Jina's therapy.

\section{Development history and family background}

It was the father's first marriage and the mother's second. As the father's side of the family did not have many girls, Jina was showered with affection when growing up. The father, in particular, indulged her. Jina had a brother who was two years older than she was, and she was particularly obsessed with him. She would listen well to what he said. The mother quit her job after becoming pregnant, but staying at home made her feel depressed and suffocated. The mother was deeply wounded from her divorce from the first marriage, and also had many unhappy childhood memories some of which included her parents' frequent quarrels, her father's addiction to alcohol, and sexual abuse by her father and a neighbour. Because of her anxiety, depression, and fear of sexual abuse, the mother did not feel comfortable with her husband taking care of Jina alone; she had to have Jina in tow at all times. In fact, when Jina was younger the mother took her to the daycare where she worked. And just when Jina reached school age, the mother began to work as an administrative officer 
at the elementary school where Jina enrolled. Because they were at the same school, Jina would always come to the mother's office and "grizzle" in tears whenever she was faced with problems. The mother's nerves were on edge over Jina'sschool life, leading to extreme intrusion into all aspects of the life of the child at school.

\section{Sandplay Process}

Jina engaged in individual sandplay therapy for nine months, from April to December of 2014. Initially Jina experienced verbal therapy together with different types of free play. The total number of therapy sessions was 25. This paper focuses on a total of 14 sandplay sessions. Sessions in which Jina received verbal therapy or played on the floor were excluded.

Estelle Weinrib (1983) defines sandplay therapy as a nonverbal, nonrational form of therapy that reaches a profound preverbal level of the psyche.Through this sandplay process, Jina demonstrated an active participation in and interaction with her inner world, including the unconscious, and the outer world, which included consciousness and/or the creation of sand pictures.

\section{Session Five - Sand picture \#1}

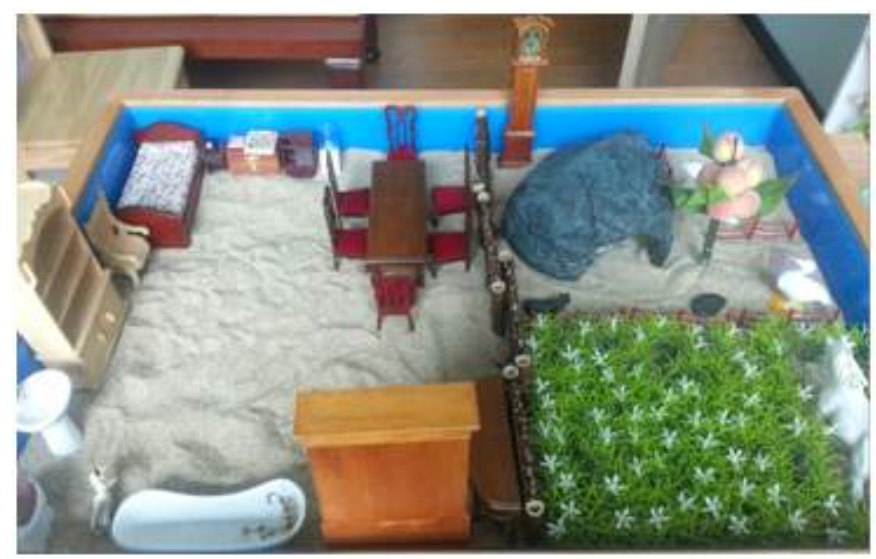

Figure 1. Sand picture \#1 
Journal of Symbols \& Sandplay Therapy, Vol.8 No.1.

Dora Kalff(1989/2012) explained that the first sand picture created often suggests what problems or challenges the clients experiencing and sometimes shows resources that are available for resolving the issues. During her initial experience with sand and the sandtray, she touched the sand, imprinted her hand in the sand, and placed fences, forming boundaries. Leaving imprints of the hands or figures signifies that sand structures in later pictures will be shaped carefully, and also represents a concrete mark of Jina's existence (Steinhardt, 2000/2010). By placing the fences in the middle of the tray, separating the right and left sides, she provided an opportunity to differentiate the opposites, in general terms. First looking at the sand picture, I thought that the opposites represented were the outside world (right side) and the inner world (left side). However, staying with the picture, I felt a paradox in that the right side seemed to represent Jina's inner world and the left side seemed to represent her outer world. Trying to understand this paradox, I felt that Jina was representing her need, felt consciously or unconsciously, to erect boundaries between herself and her mother.

It seems that the act of erecting fences represents Jina's erecting a boundary in the unconscious as she goes on a journey to recognize herself as an individual and separates psychologically from her mother; in other words, develop consciousness.

Jina first placed larger figures inside the house, and carefully chose smaller figures such as a sewing box, a telephone, and a water dispenser to fill the rest of the picture. I felt that this choice of figures seemed to be an expression of her desire for communication with her inner world and organization within, perhaps from a state of chaos. Upon seeing that a bathtub, a washstand, and a toilet were placed in the left near corner, I felt that the area will become a place of purification, a place for healing in the unconscious. Only after quite some time had passed since the beginning of therapy was I able to hear that the mother had been abused sexually during childhood. During parent consultation, I realized that the mother's belief that she is a tainted human being has influenced her life and her obsession over Jina.

The reindeer next to the washstand is not what one would typically find in the home. Reindeer is a species of reindeer with large antlers that are unique in that the long tines point backward. Reindeer symbolize creative divineness, and the antlers are a symbol of the masculine (Leonard, 1995). Rein deers can be found mainly in parts of North America, especially Canada. 
Perhaps the reindeer in the picture is both a symbol of the masculine that is related to the mother's experience of being a victim of sexual violence, and a symbol ofJina's divine creativity. Leonard (1995) writes that shamanic people in the Arctic recognize the reindeer as "spiritual messengers who travel between heaven and earth" (p.23).

The right side of the first sand picture, or Figure 1, seems to represent the outer world, the world of Jina's outer reality. She had divided the right side into two: near and rear. The cave in the right rear quadrant is a symbol of the Mother archetype. It appears to project the mother's overprotection of Jina, her anxiety, her being unable to separate from the child. The cave, a place of darkness and containment, symbolizes that psychological space where something old (e.g., beliefs, behaviors, etc.) can die and something new (e.g., attitudes, thoughts, ways of behaving)can germinate and develop. Thus it symbolizes the potential for death and rebirth.

In Asian mythologies, the peach tree is considered a tree of life and a healing elixir. The ones who eat the fruit are said to receive immortality (http://japanesemythology. wordpress.com). The peach tree or the fruit also symbolizes spring, youth, marriage and the spell for protection. It was also believed that the tree has the power to chase away evil spirits (Tresidder, 2000). In this sand picture the peach tree is standing in front of the cave, symbol of the mother archetype, as if to protect it. The three shells surrounded by fences in the right rear corner seem to indicate the development of the feminine in Jina, which was not functioning at the moment.

In the grassy area in the near right quadrant stands a white horse, digging its hooves into the ground with its head lowered. According to Turner (2005), the way that the grass is rooted in the ground and spreads out widely makes it a symbol of individuation. It also suppresses the ground, or the unconscious, beneath it. As Dalziel (2005) writes: "We would never expect a blade of grass to grow away from its roots."

The white horse is usually considered to be a symbol of divinity (Turner, 2005). Perhaps this symbol of divinity on the grass, with its head lowered and its hooves digging in, suggests mediation between consciousness and the unconscious, or a process leading to the integration of spirit and instinct that is essential to the development of an ego that is 
Journal of Symbols \& Sandplay Therapy, Vol.8 No.1.

functional and adaptive in the outer world. The reindeer and the white horse have a commonality in that both their heads are toward the ground. The reindeer is on the left side, meaning that it seems to symbolize Jina's unconsciously identifying herself with her mother.

A prominent characteristic of this sand picture is the fencing. Perhaps this is an indication that Jina is ready to set some individual boundaries and begin the separation process with her mother in order to develop her own unique potential.

\section{Session Six - Sand picture \#2}

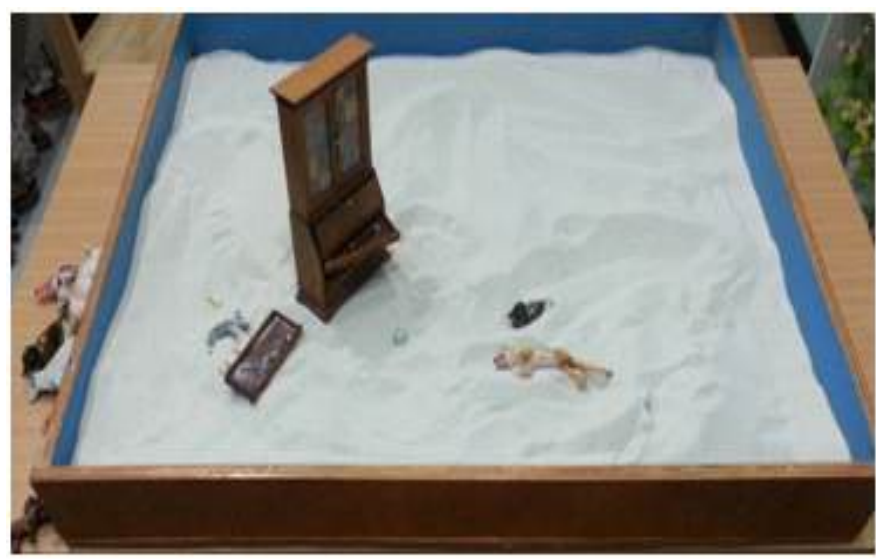

Figure 2. Sand picture \#2

Wanting to play a game of burying and searching, a sort of hide-and-seek, with the therapist by burying figures is Jina's expression, through play, of wanting the therapist to notice or verify her inner contents. The act of burying can be also be understood as trying to protect one's precious things or shadow domain from the outer world (Turner, 2005). They can be viewed as Jina's overly compensating herself for the lack of a positive mother archetype that is sensitively attuned to the child and makes the child feel safe and contained. The stethoscope allows one to hear the beat of the heart to check its condition; the heart is a symbol of life or living, a vital symbol. A sensitively attuned mother is able to respond to the child with expressions and emotions that correspond to the child's present condition, and through those responses the child is able to feel his or her own emotions. By remaining steady 
and consistent, the mother is also able to help the child learn to self-regulate his or her emotions, and assist the child in knowing that he or she will survive (Schore, 2012). The cutlery in the picture represents tools for eating, and therefore suggests a symbol of compassionate nurturance.

Among several figures left in the final scene after a series of play in the sandtray, there is the white fox that in nature is adapted to camouflage itself in the snowy environment, protecting itself from the polar bear and other prey. Almost half-buried in the white sand, the fox in the tray is hardly visible. It gives the impression that Jina is unconsciously trying to protect herself from her mother's devouring energy, which is constantly focused on Jina. It is probably also related to the outer reality in which Jina is not able to communicate well with her peers and tries to conceal herself.

Jina made lots of requests and gave directions to the therapist during the play. As the level of her determination to control the play was high, I surmised that Jina would behave in a self-centered way when interacting with her peers. On the other hand, Turner (2005) did mention that through the play of burying and discovering figures, clients are able to gain control of what is beyond their control in outer reality. In order for Jina to achieve a balance in relationship and communication, she must first achieve balance in her inner world. In order to do so unconditionally, positive mother archetype energy is essential, as confirmed by many previous child development studies. When a child identifies himself or herself with the parent and has not yet reached the developmental level of psychological separation, often also he or she is unable to make a distinction between his or her inner and outer worlds (Jang, 2017). Another symbol in this sand picture, is the tiger, a symbol of transition and rationality (Kalff, 1989/2012). The Latin word for tiger is tigris, meaning woman, and so the tiger also symbolizes the dark feminine (Kalff, 1989/2012). The tiger forecasts that Jina would gradually develop and become separated from the state of mother-child unity. But the fact that the tiger is lying down and sleeping seems to suggest that Jina remains in the stage of participation mystique, unable yet to connect with the energy of transition. Perhaps this is why the sand picture appears barren and lonely overall.

A movement by Jina that was also noticeable was that she tried to put many glass 
Journal of Symbols \& Sandplay Therapy, Vol.8 No.1.

beads into the drawer for a long period of time. The ones she did manage to put into the drawer seemed to symbolize "deintegrates" or pieces of the Self that are yet to be integrated. But at the same time, the single bead left on the sand seem to indicate that Jina, at least unconsciously, recognizes herself as whole and ready to transition into the next stage of the development of the conscious. As Neumann (2004, p. 43) states: Although initially the evolving ego consciousness is dominated by the uroborus or primal unity stage, it is not solely embryonic. Although still in the Great Round phase of development, rather than separated from it, it is the beginning of its own existence.

\section{Session Seven - Sand picture \#3}

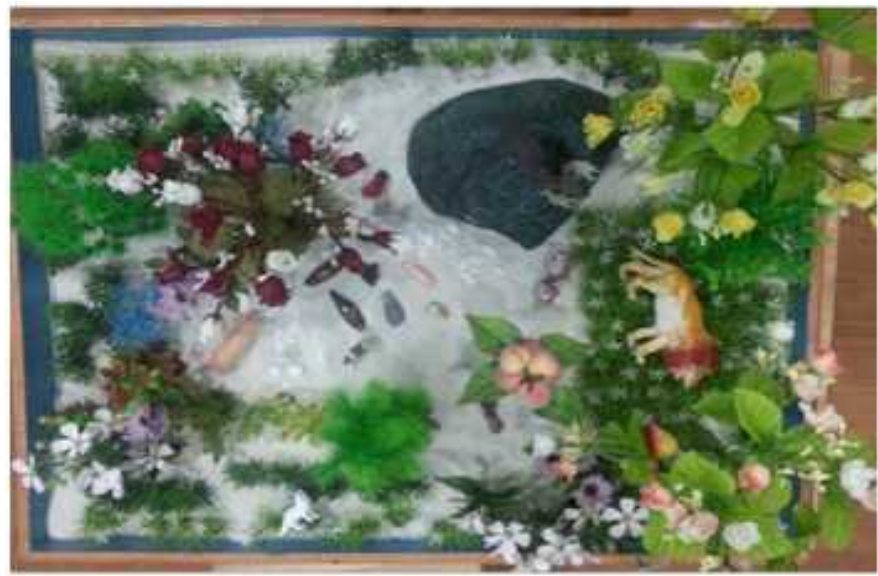

Figure 3. Sand picture \#3

The white fox which was half buried in the sand in the second session now became a "Creator" who would watch over the animals and even control them. Whereas the white fox in the previous picture appeared unable to carry out the ego function, the fox in this sand picture seemed to represent Jina's effort to protect herself from the negative mother complex through the symbolism of the archetypal "Creator" energy. Also, given that plant figures were lined along the edges of the tray, creating a second boundary, I could feel a sense of wariness toward her mother, the therapist, and the outside world. 
A moose is standing atop a cave, an archetypal mother symbol. Moose have wide hooves and a strong lung capacity, both of which contribute to the moose's being excellent swimmers. Being able to dive underwater for 40 seconds, moose are capable of feeding on underwater plants. They have sharp olfactory and auditory senses and are able to travel smoothly on swamp lands and snowy grounds (https://ko.wikipedia. org/wiki/). A bird's-eye view of the sand picture shows that the moose's antlers form the shape of a mandala, and a symbol for solar energy.

A lion is lying on its side on the grass. In front of him are two meerkats, standing as if they are on guard. A male lion is related to solar rationality (Neumann, 1973); it is also a symbol related to consciousness. This symbol heralds the transformation from a primal mother-child unity to the development of consciousness; it signifies the gradual separation of the child from the mother. Whereas the tiger that appeared in session 2 relates to the negative mother realm in terms of a fierceness and boundary-setting attitude that the mother displays, in the service of separation from the mother-child unity stage (Neumann, 1973), the lion in this picture symbolizes the rational father or masculine realm. "The lion, as the king of the animals, is associated with the sun because of his yellow coat. The lion symbolically alludes to a clearing up of the conscious mind. The lion's vitality speaks for energies that are ready to awaken. Since the tiger descends from the podium in the center and the lion is on the point of ascending it, we can assume that this indicates a transformation in client's development" (Kalff, 1989/2012, p.103).

The place where the lion is lying is a differentiated space marked by the almost-square patch of grass. The square form and lion are usually suggestive of ego energy and consciousness (Kalff, 1989/2012; Neumann, 1973). However, in this picture, that energy is not yet activated. The presence of flowers in the grassy square suggests positive feminine energy perhaps from the archetypal Great Mother. As Kalff (1989/2012) and Weinrib (1983) emphasize, a healthy ego depends upon nurturance by bits of Self energy for its development. The grass, which roots deeply in the ground, impedes other plants such as weeds to take root. It also suppresses negative aspects from surfacing on the ground, in other words, in the realm of consciousness (Dalziel, 2005). 
Journal of Symbols \& Sandplay Therapy, Vol.8 No.1.

Just as the sleeping lion may suggest, according to Neumann (1973), the solar rational or Patriarchate stage, healing and development must occur before the archetypal energy represented by the lion symbol can be activated. One of these necessities is a constellation of the Self and the gradual transition from the primal unity stage to the stage of the Father. In several pictures to follow, when the lion begins to be activated and move around the tray, we see the peach tree beside him, probably as a protective energy and perhaps to keep away the mother's "ghost" in the form of her former sexual abuse, so that Jina can develop.

Meerkats live in large underground networks in a group and they are always guarding at the ground level. They are immune to certain poison and thus can eat scorpions or poisonous snakes. Meerkats inhabit dry open areas; they are not usually found in forests or mountainous areas. Living underground keeps the clan members safe from predators and out of the harsh heat. These burrows can be 5 meters long. In some parts of the African continent like Zambia and Zimbabwe, meerkats are considered "Angels of the Sun" that protect the village (http://terms.naver.com/entry.nhn?docId). Such characteristics of meerkats invoke Jina's ambiguous perceptions of the attitudes of the mother, Jina herself, the therapist, and the Guardian Spirit energies previously discussed. Angels of the Sun, who live in the darkness of the underworld, again suggests a bridging of opposites of consciousness and the unconscious.

As mentioned already, Jina dominated the mother's thoughts especially at school. She would peek through the classroom window to check on Jina. As for Jina, she would burst into her mother's office crying whenever she faced difficulties at school. As therapy progressed, the mother reported that while Jina had stopped coming to the office so often, she still felt anxious and could not keep her mind off of her child. It seemed that Jina was in a transitional stage with ego consciousness beginning to develop out of the primal mother-child unity phase when the unconscious was dominant. She was gradually experiencing rational thinking and self-regulation of her emotions. 


\section{Session Ten - Sand picture \#4}

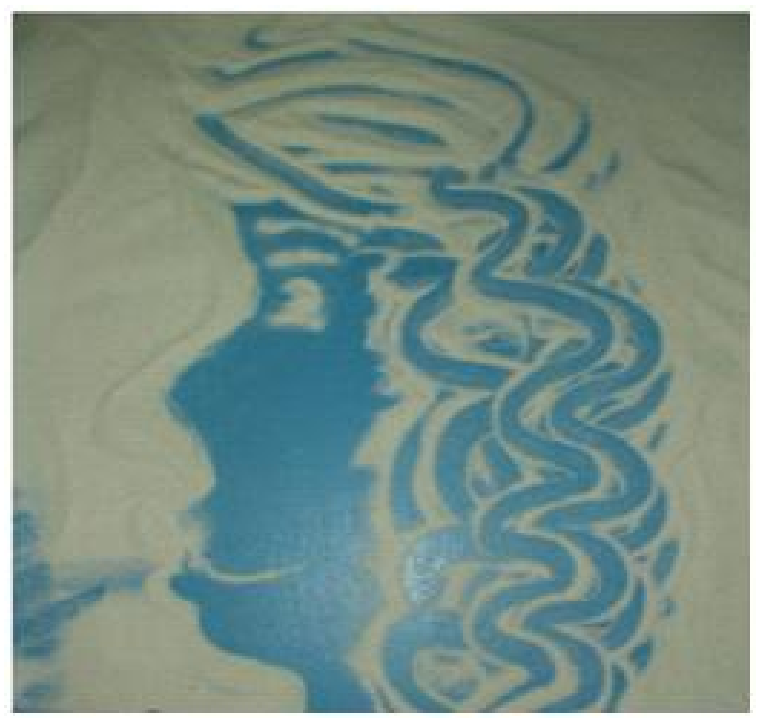

Figure 4. Sand picture \#4-1

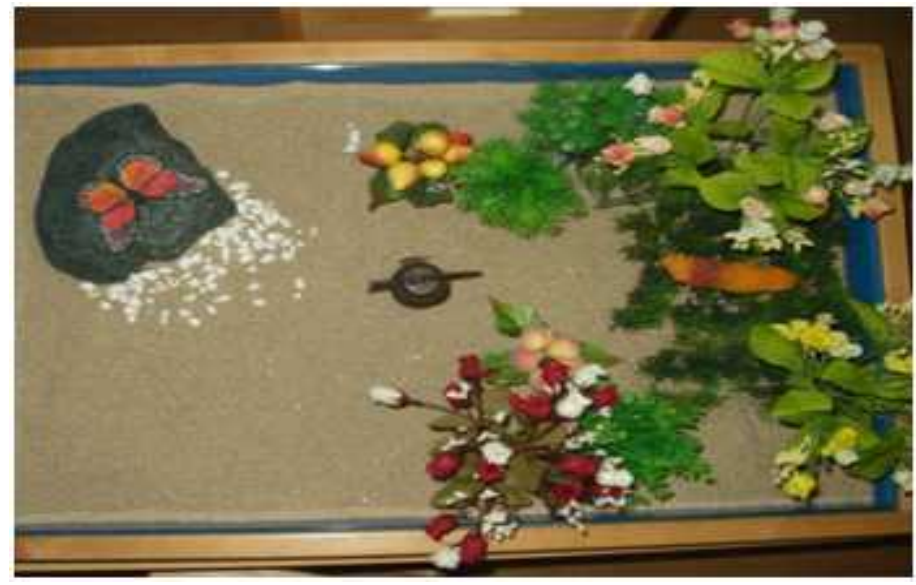

Figure 5. Sand picture \#4-2

The previously sleeping lion was now awake and standing on a patch of grass. This change meant that the child was becoming separated from the mother and was also beginning to develop rational consciousness as symbolically represented by the male lion (Neumann, 1973). 
Journal of Symbols \& Sandplay Therapy, Vol.8 No.1.

Perhaps the ringing of the bell at the center of the tray had awakened the sleeping or undeveloped consciousness. Though Jina was not consciously aware, her unconscious would know that it is connected to a healing instinct.

In sandplay therapy, the center area has a highly important meaning as it is related to the Self archetype. Symbols that appear at the center are connected to the cosmic axis, and induce the constellation of the Self, which is the beginning of the development of a healthy ego (Eliade, 1990). I felt that the sound of the "Emille Bell" placed at the center of this sand picture echoed throughout the therapy room and filled the place with sacredness. That echo will probably allow sandplay therapy to enter a sacred moment that is beyond space and time (Turner, 2005), the presence of numinous energy which facilitates the process of constellation of the Self which we will see later.

As I continued to look at the center of this sand picture, the space around the bell seemed to become sacred, holy. The child played with other figures outside of that area, for example, the white fox. However, she did not move any figures into the holy space or touch the bell again.

Jina carefully drew a woman in one sandtray (Figure 4) and created a sand picture in another (Figure 5). When I looked at the image of the woman, she appeared to be a Medusa-type figure, although Jina was not aware of the Greek myth of Medusa. Also, the woman she drew was not depicted in a frightening way. Turner (2005) said that she is always in awe whenever she witnesses a child's sandplay with mythological themes. I too felt awe, sensing this connection with the collective unconscious. In the myth, Pegasus appears after Medusa, the Dark Mother, has been killed, exemplifying the new creative development that may follow a psychological death. Interestingly, I could feel Pegasus's energy of transformation from the butterfly.

Medusa is a symbol of the negative mother complex. Erich Neumann (1973) wrote in his book The Great Mother that

the petrifying gaze of Medusa belongs to the province of the Terrible Great Goddess, for to be rigid is to be dead. This effect of the terrible stands in opposition to the mobility of the life stream that flows in all organic life; it is a psychic expression for petrifaction and sclerosis. The Gorgon is the counterpart of the life womb; she is the womb of death or the night sun.(p.268). 
Jina wanted to show the woman's picture to her mother. Perhaps Jina's unconscious wanted to show the mother the healing energy that had become connected to Jina with that transformation from the terrible image of the mother.

In Korea, too, intrusive mothers are often called "helicopter parents." It seemed that the mother's over-protective attitude had seriously impeded Jina's development of ego-consciousness, which is what the negative mother archetype does in its devouring phase. This session let us know that Jina was ready to separate from the mother world and carry out necessary tasks for the development of ego-consciousness.

\section{Session Eleven - Sand picture \#5}

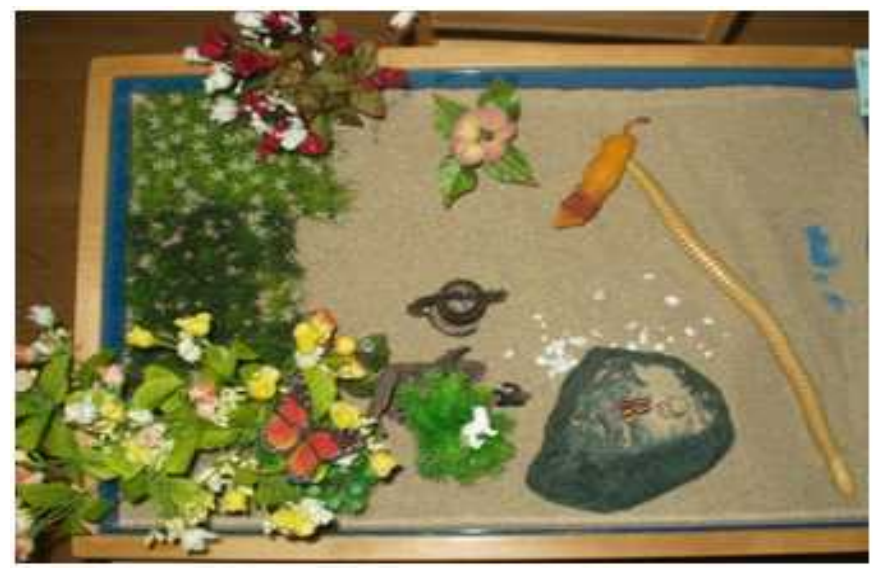

Figure 6. Sand picture \#5

Judging from how the story from the last session was being repeated, it seemed that the act of doing a role play contained some important issues of Jina. Turner explained that Jina's psyche is affected by the themes of active play, and advised that therapists should pay attention to mythical themes and patterns of movements that lie beneath the play itself. When there are movements in the child's sandplay, the psychic energy is able to shift and a passageway for energy is created.

The "Creator" or the white fox was the one with control in Jina's role play world. It was a figure that contained both the issues of the negative mother archetype and also Jina's 
Journal of Symbols \& Sandplay Therapy, Vol.8 No.1.

self-centered peer relationships. It played an important role in the overall context of Jina's sandplay process. As it was sometimes associated with the mother and sometimes Jina, it could be said that the fox represents Jina's inner world in which there is an ambiguous psychological boundary between the mother and Jina.

The lion that had been lying on the grass in the previous session was standing up on the sand in this session. This configuration meant the connection between the unconscious and the conscious, or the connection between Jina's inner world and outer world, was alive.

The big snake on the right side of the tray was a green snake, but the configuration made it difficult to see its color. The green snake is a symbol of healing. Looking at how it was positioned, it seemed that the snake was in the process of leaving the tray. The lion standing by the snake's tail represents both masculine and feminine energies. The snake's tail was placed right beneath where the lion's penis would be. This could mean that the mother's experience of sexual violence, her fear of men, and her guilt are finally leaving her, or at least the unconscious of the daughter.

\section{Session Thirteen}

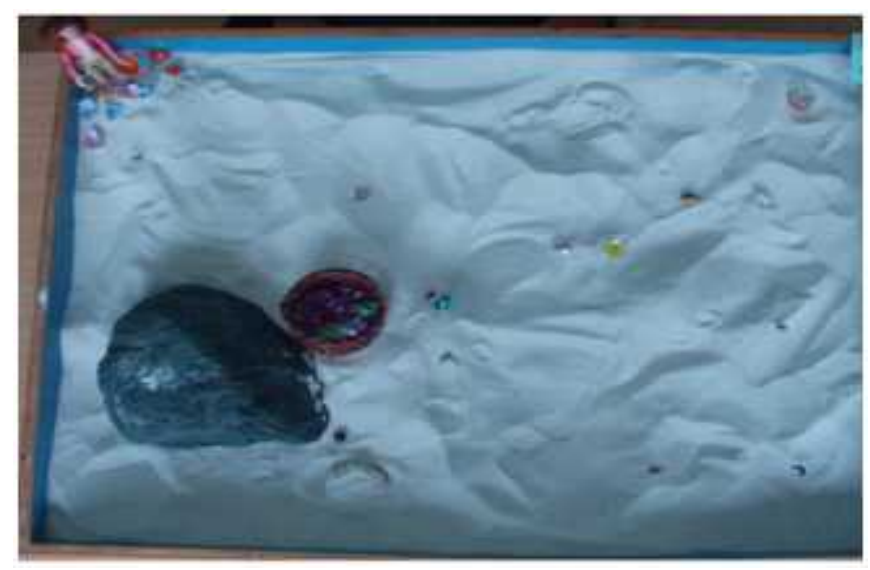

Figure 7. Sandpicture \#6

The most eye-catching part of this session was the woman, who resembled Jina's mother. Jina's mother, in real life, had come to recognize that her concerns over the child 
were unnecessarily excessive. Perhaps the mother's awareness of herself induced some changes in Jina's psyche, which could explain the appearance of the woman figure. Instead of the devouring mother energy of Medusa, there was an image of a personal mother. This could indicate a transformation of Jina's image of her mother.

There were many "containing" figures such as the cave, basket, and glass bottle. Through these figures I could see that the Great Mother energy, a positive mother archetype, was present in the sandtray. Given that the cave was empty, I thought that it may be an unconscious symbol for the Great Mother's containing energy. The mouth of the cave was facing left, which hinted that there was a connection to the unconscious. This was also where the therapist was sitting, which could also mean that the positive mother archetypal energy of containment was being projected onto the therapist. Food scattered across the sand are also symbols of nurturing, one of the characteristics of a mother archetype.

The woman's legs are half buried in sand, making it difficult for her to move about freely. As mentioned above, it seems that there is some connection with Jina' personal mother and her development in becoming more conscious and less susceptible to unconscious forces. As well, we can see this figure as representative of something happening within Jina. It seemed that she was in the middle of trying to free herself from the sand, from matter, from the Mother with whom she has been in primal unity. If so, it seems to indicate that the ego was awakening from the unconscious. The small jewels placed around the woman also seemed to indicate the manifestation of the Self, which facilitates ego development. I thought that the Great Mother energy in the sandtray was a positive mother archetype that nurtures the Self. And as mentioned already, the jewels contained in a basket seemed to indicate the initial stage of the manifestation of the Self. I felt that all of these positive mother archetype symbols would facilitate the child's development and independence.

\section{Session Fourteen}

Jina buried heart-shaped crystals and keys in the sand and played a game of unearthing them with the therapists. She then returned the crystals and keys back to the shelf. Initially Jina's game of hide-and-seek involved animal figures. That the hidden figures changed 


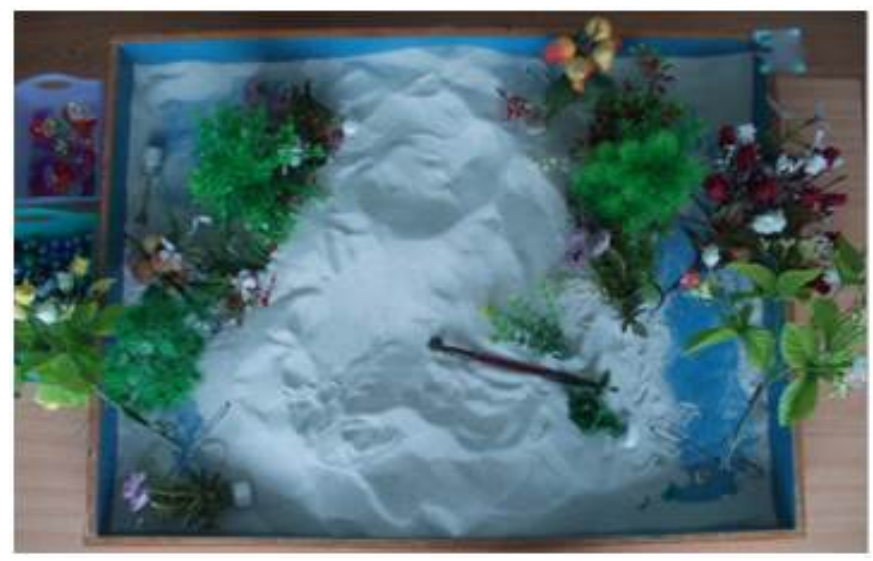

Figure 8. Sandpicture \#7

to crystals and keys perhaps may indicate that the personal aspect of Jina's psyche became more clearly manifested. Jewels and crystals are a symbol of the Self (Ackroyd, 1993), and the key seemed a signal from the unconscious that allows Jina to access her true Self. As Birkhauser-Oeri (1988) emphasizes, going into the unconscious is part of the process of attaining development of conscious, and images of the key enable access to the treasures of the unconscious.

After the game of hide-and-seek, Jina buried jewels and glass beads in the sand and created a big mountain. We could see this big mountain as a sacred mountain, which is a symbol of the Self, a necessity in attaining a higher dimension of development (Turner, 2005). The act of centering is related to the Self archetype and thus has an important meaning in sandplay therapy. Symbols that represent the center are related to the axis mundi. The center is the archetypal center of the world; the mountain is considered a place where it is possible to ascend towards another dimension or stage. Many times do we see clients creating a mountain at the tray'scenter.

Cooper (1978) said that the mountain has the shape of a grave, also having the function of containing a corpse. While the mountain, sometimes compared to the mother's breasts, is considered to hold positive mother archetypal energy, it is also considered to represent negative mother archetypal energy, in this case, related to death, as mentioned by Cooper. 
As said already, the mountain has both positive and negative mother archetypal energy. It is compared to the mother's breast, a symbol of life. But it is also used as a metaphor of a grave, a symbol of death. Throughout the therapy, the mountain acts as an important symbol for Jina's ego development and individuation process. The fact that a big sacred mountain containing treasures is created at the tray's center seemed to imply the manifestation of the Self. I felt that Jina was burying something precious to her in the mountain out of her need to protect what is very valuable, especially from an intrusive mother. In fact while creating this scene she said to herself, "So that other people wouldn't be able to find them." The jewels within the mountain seem like seeds for the flowers which abundantly bloom and cover the mountain. I had a sense of the constellation of the Self in this beautiful and numinous picture filled with dynamic energy. There are so many layers to it, in terms of the jewels, the sacred mountain, the axis mundi, and then the abundant life energy of the flowers, plants, and the peach tree at the front centre. After creating this picture with what seemed a holy attitude as in a spiritual ritual, Jina paused for a couple of moments. Then she took the picture apart. At that moment, I felt disappointed at seeing this beautiful picture disappear. However, as she began to take each of the jewels out from the centre of the mountain, I soon felt a sense of completion. I understood the act of destruction on two levels. On one level, I saw it as completing the archetypal image of creation which holds its opposite, destruction. As well, I felt because of what she had said earlier that she needed to do so in order to protect her creation, both in the sandtray and in her psyche.

The long smoking pipe that Jina used to create and unearth the mountain symbolizes masculine authority and values in Korean culture. To Native Americans, the smoking pipe symbolizes peace. The expression "pipe dream" is about imagination (https://en.wikipedia.org/wiki/ Pipe_dream). The smoking pipe figure seems to indicate that session 14 is connected to Jina's realm of imagination. The realm of the imagination is connected to unconscious associations. This part of the sand picture seemed to indicate the search for equal rights of the feminine that were violated by the masculine. And Jina's use of the smoking pipe-a masculine symbol-to create and destroy the mountain-a mother symbol-made me wonder if Jina was sharing, at an unconscious level, her mother's experience 
Journal of Symbols \& Sandplay Therapy, Vol.8 No.1.

of sexual abuse (Ackroyd, 1993).

\section{Session Fifteen}

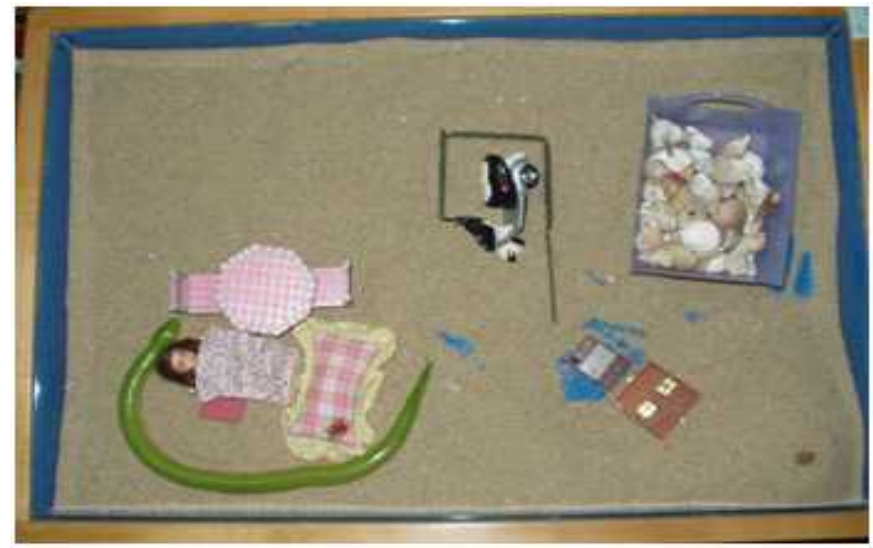

Figure 9. Sandpicture \#8

The green snake forms the shape of a container, and the sleeping girl on the bed is inside that container. The formation suggests that healing of the negative mother archetype is occurring through the act of sleeping, or being in an unconscious state. The "fence" created by the green snake is not entirely closed off; yet it reminds me of a uroborous. An image of a snake in the form of a uroborous can symbolize the mother-child primal unity stage (Neumann, 1973) and also contains the opposites-destruction and creation-of the mother archetype (Cooper, 1978). This image suggests that something is happening at an archetypal or deep collective unconscious level. Sleeping suggests going deep into the unconscious. Weinrib (1983) said that a client's sandpicture represents the journey to the rearrangement of the Self, and that this journey is connected to healing and development. Healing is a precondition for development. The color green is considered important in Western religions, being a symbol of leaves, an oasis and a refuge. In Islam, it is considered a symbol of a protective, peaceful shadow. Considering these facts, the green snake can be viewed as providing energy for healing (Turner, 2005). As Jina created this picture in silence, I could feel rest, healing and peace in the session. 
Jina directly expressed her discontent at the white sand, which she had used previously without complaints. This led me to believe that she had begun to communicate her emotions directly. Jina brought a basket full of seashells-symbols of feminine relational energy-and explored them, commenting that she likes shells very much. Her activity with the shells looked as if she was taking care of both her and her mother's feminine. The fact that Jina dressed like a boy, engaged in aggressive play that is more typical of boys than girls, and tried to hide her feminine aspect can be interpreted as her defiance against maternity. The sleeping girl, under the protection of the green snake, seems to foretell the rebirth of the feminine (Cooper, 1978).

The right near quadrant of the sandtray is the area of the personal mother, or the area related to the body, according to Ammann (2001). A turd figure is buried in this area, through which I made an association to the mother's breast. This indicates something related to the personal mother; perhaps also to the healing of the feminine wounded by the mother's sexual experience. I found it highly interesting that I made an association between the turd and a breast. It seemed to be attributable to one of those "magics" cast by the "Jina in the camera" that I hear Dora Kalff sometimes referred to. I felt that the breast represented a recovery toward the nurturing mother archetype while the turd represents something that can now be eliminated.

Typically, as a child grows up, when he or she becomes independent from the mother's breast, the child begins to suck a lollipop. Perhaps in the case of Jina, the presence of these items in the tray symbolizes that the child has separated from the mother's breast and has developed the ego, at least in its beginning stages. In this session, the figures symbolizing several represented containers show the positive mother archetype needed in child development.

The biggest change noted in this session was that Jina had called the girl figure "Fox," which was referred to as "Creator" in the previous session. This led me to wonder whether the fox or the Creator was the girl all along. Perhaps the girl symbolically represents an unconscious urge to create her life independently and autonomously, like the "Creator" would be able to do. What also caught my attention was that the fox, which had appeared as 
Journal of Symbols \& Sandplay Therapy, Vol.8 No.1.

an ancient, mythical symbol, became a more personal and subjective symbol in this session. I felt that maybe the symbolism of "Fox" is an internal symbol and at the same time the image of the mother, a symbol of the girl's newly developing identification with her mother and the Feminine.

\section{Session Sixteen}

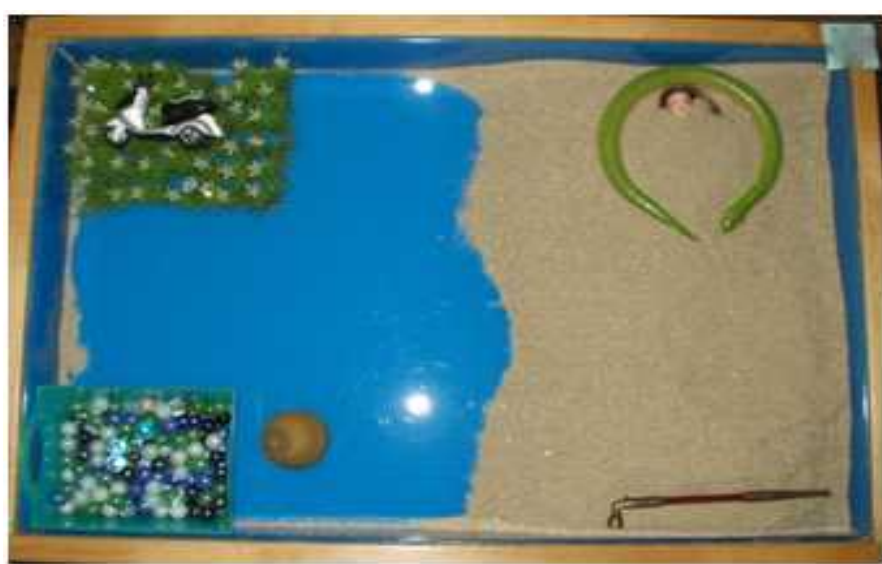

Figure 10. Sandpicture \#9

The blue bottom of the left side of the tray-which is considered an area of the unconscious-is exposed. The girl figure appears to be in deep sleep inside the sand; the orientation seems to represent going deep into the unconscious, symbolized by being buried in the sand. Here I was able to see a clearer form of the uroborous than in the previous picture. Neumann (2004) explained that the being inside the uroborous is a self-expression of early childhood in the form of the mother-child unity of mankind. The way the girl is inside the uroborous suggests that the Self is nurturing the ego for a safe psychological separation between the mother and a child; in other words it foreshows the development of a healthy ego. An ego that is not nurtured by the Self becomes either inflated or empty, and cannot function properly (Weinrib, 1983). With the girl's body buried in the sand and her head above, Jina emphasizes the connection between consciousness and the unconscious that is essential to healthy ego development. 
The breath of life, which Jina called "good smoke," will allow the girl to face a moment of rebirth through which the body and the mind communicate. As if to predict this process of rebirth, Jina played with toy cars on the floor before creating the sandpicture, and acted out a scene where everyone dies. She talked about how it is difficult to survive there. "Being that has soul is living being. Soul is the living thing in man, that which lives of itself and causes life. Therefore God breathed into Adam a living breath, that he might live" (Jung, 1984/2002, p. 136). The breath that wakes the soul, which Jina described with the crystal ball, allows the Self to become manifested. As for the glass beads in the basket, they can be considered a symbol of the Self's deintegrates that are beginning to be manifested to become whole.

The left half of the sandtray is considered an area of the unconscious or an area where mother archetypal energy manifests. Jina carefully cleared sand away from the area and placed a tuft of flower-grass, on top of which lay a scooter. This formation looked as if the masculine being contained on top of a feminine base.

The turd figure is a symbol for elimination, eruption and excretion. When food is digested, the nutrients are absorbed by the body and the residue is excreted in the form of feces. The soul also needs to be purified through such process of excretion. In Jina's case, we can think of purification or healing of the mother's guilt and humiliation stemming from her childhood sexual experience. Unhealed feminine energy reinforced the mother's complex in both her and her daughter's unconscious, especially over how she was not protected by her own mother during the sexual abuse. As a result it became dysfunctional: the mother became obsessive over Jina and unable to separate from her.

The smoking pipe is a symbol for masculine communication and peace. In this sandpicture, it was used as a tool for the girl to inhale good smoke. This seemed to indicate her wanting to better adapt to peer relationships by unifying her feminine and masculine energies. In fact Jina said to the girl figure in the tray, "You can play again after inhaling the good smoke and taking a good sleep." I could feel the emotions contained in that comment; I was greatly moved as it was as if those warm words were comforting the girl. I also felt that the comment reflected Jina's wanting to enter the next stage of development through her ego 
Journal of Symbols \& Sandplay Therapy, Vol.8 No.1.

development, by separating herself away from the uroboric form or the mother-child unity.

\section{Session Seventeen}

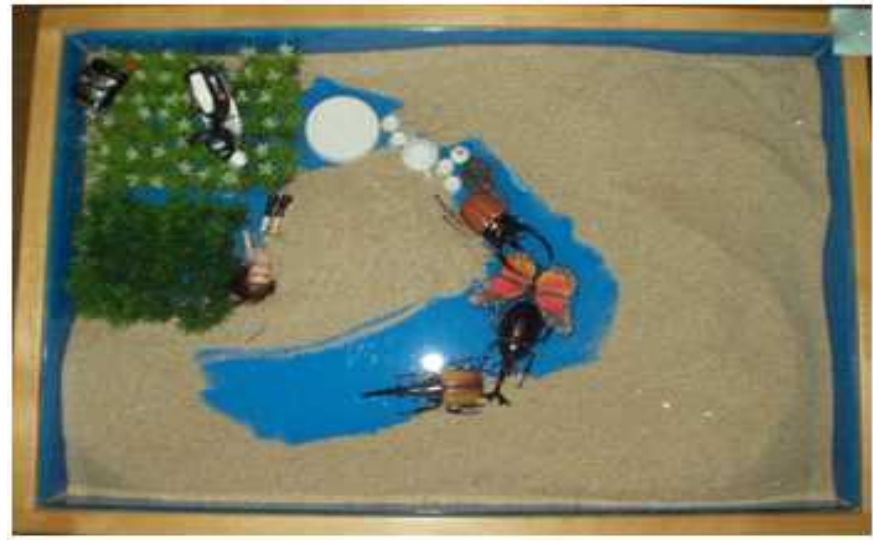

Figure 11. Sandpicture \#10

The grass figure, which was placed on the sand in the last sandpicture, is now located on the exposed blue bottom of the tray. The change led to the assumption that consciousness was developing between the unconscious and consciousness. The blue bottom underneath the grass extends like a river meandering its way through. Just as waterways naturally become connected, there will be a communication between the conscious and the unconscious in this liminal space. It also foretells the union of the Self with the ego. Jina repeatedly conducted a play of pouring sand in and out of the teapot or cups. The containers perhaps may be a containing positive mother archetype that promotes healing from the child's negative mother archetype

The girl who was sleeping underneath the sand previously within the circle of the uroborous, now is awake. Jina had said that the girl would be able to play again after waking up from the sleep; true to her words, the girl woke up in this session. It seemed to indicate the awakening of Jina's ego-consciousness. Jina called the girl Fox; in previous sandpictures a white fox by the name of Creator had appeared. Just as Jina's mother shed off the image of Medusa-a negative mother archetype-and emerged again as a personal mother, it appeared to 
be a moment where Jina broke from the form of an instinctive and ordinary animal and is born again as a human being. The girl named Fox moved actively around the sandtray and emanated dynamic energy. Jina was probably able to recognize herself as an experiential being through a psychological separation from the mother.

Four types of insects are in this sandpicture: the rhinoceros beetle, butterfly, stag beetle and long horned beetle. These insects share commonalities: they all go through metamorphosis, endure the pupal stage and are born again. The girl figure who woke from a deep sleep inside the uroborous, like the larva inside the cocoon who transforms into a pupa and then a mature form of the butterfly, symbolizes the moment of a new birth.

I made note of the fact that the scooter-symbol of the masculine and the ego-was standing upright. With healing from the negative mother archetype Jina will develop masculine rationality which will enable her to function well, or better than she had previously, with regard to peer relationships. This part of the process is seemingly connected to Jina's development of sociability, which was delayed. Next to the scooter was a Bible. Religious texts like the Bible are the highest form of educational book for mankind, containing the wisdom of the spiritual realm for human healing. May the words of wisdom be with Jina's development.

\section{Session Eighteen}

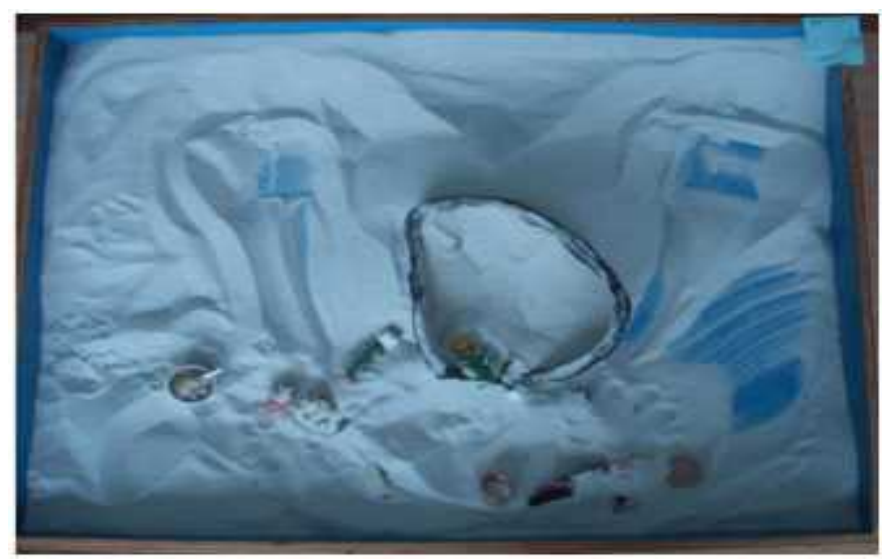

Figure 12. Sandpicture \#11 
Journal of Symbols \& Sandplay Therapy, Vol.8 No.1.

Jina asked me to change the beach sand tray into a white sand tray. Changing the tray represents an emotional transformation on the part of Jina. The brown beach sand is commonly seen in our everyday lives and is related to the external world or the instinctive realm. On the other hand, white sand is not commonly seen in the outer world, and the color white is connected to the spirit or the internal world. After switching the tray, Jina openly talked about how she viewed her family. Up until this point, Jina had been rather secretive about her family and avoided talking about it. Therefore the stories of her emotions and feelings and about her family gave the impression that there was a transformation in her psyche.

The capsized cave is a symbol of change and can be viewed in connection to the snake or teacups that were also upside down in previous pictures. Themes or situations related to being capsized, confused and messed-up often appear in sessions that herald transformation or rebirth. Eliade(1990) said that the cave is a sacred place, the womb of the earth from which new life is created. In many cultures the cave is considered a mystical place. In Jina's sandpicture, this sacred realm was turned over, spilling out what was contained inside. The jewels, food and flowers scattering to different directions represent dissociation, chaos and explosion; it is likely that the chaos will lead to a new turning point for relationships. I felt that it was a moment marking the destruction of the sanctuary of the personal mother, and also a moment foreshadowing the death of the negative Mother archetype. The cave symbolized the positive Mother archetype that was possible within the therapy process; now that cave is capsized, exposing the items inside(Lee, 2013). With containment, protection, and nurturing from the positive Mother archetype, there has been healing from the negative Mother archetype.

Seeing the image of two fists clenched as if in anger, I was reminded once again of the fact that sandplay therapy contains the unconscious emotions of clients. The fists pushing the sand also seemed to demonstrate a fierce determination to push against what was holding her back. 


\section{Session Twenty}

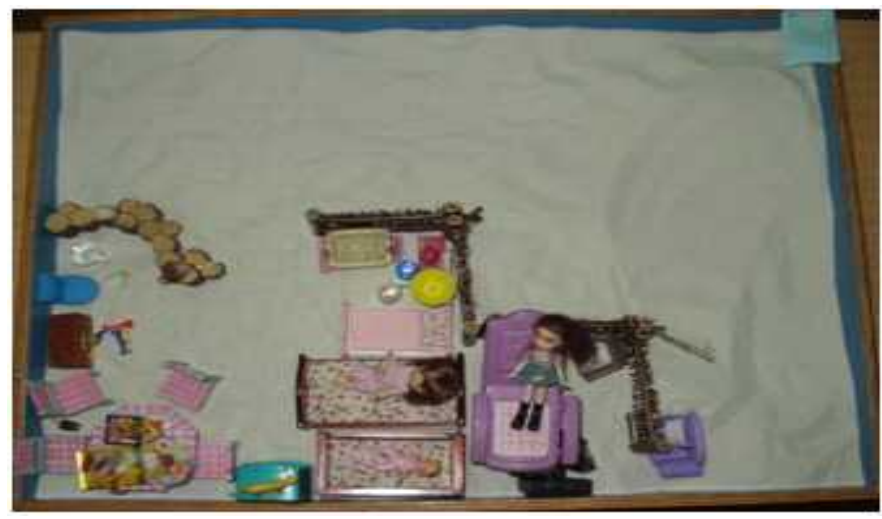

Figure 13. Sandpicture \#12

Many archetypal symbols, as represented by the figures, appeared in the previous session. But here the figures are much more related to everyday, outer life. The change could be seen as a representation of Jina's psyche undergoing a transformation, shifting from the inner, imaginative realm towards the issues of the external, conscious world. According to Turner(2005), sandpictures that depict scenes of everyday life usually show up near the final stage of therapy, and such sandpictures are related to one's entering his/her unconscious realm and reorganizing the Self archetypes and his/her psychic world. In other words, Jina became aware of her outer reality in a more accurate and objective manner and thus became more acclimatized to it. This statement is in sync with the mother's report made at this time that Jina had become increasingly adapted to school life and no longer felt so much discomfort among her peers.

The Creator and Guardian Spirits no longer are in the sandpicture. Instead, there are a doctor, a patient and a pet. And Jina gave less directions and made less requirements than she had done before. It can be said that changes in the issues in the sandpicture are connected to the changes in her ego development. The girl who had been called "Fox" and had awakened from a deep sleep plays the role of a doctor, and a younger girl figure appears as a patient. There was also a baby figure, whom Jina identified as "the doctor's baby." The appearance of the baby is important. I feel as if Jina's gradual development is shown with the 
Journal of Symbols \& Sandplay Therapy, Vol.8 No.1.

flow of time, represented by figures of different ages. Moreover, the baby and the pet cheetah, both of whom require nurturing, indicate the potential activation of a positive mother archetype.

A hospital is a place for healing, and hospital figures are often used as a symbolic representation of the therapy room. Here the dental hospital is also a metaphorical representation of the complex relationships that exist amongst the people there, in this process involving the child, the therapist, and the mother who must remain connected to the therapy in order to develop her own differentiation of consciousness and the unconscious. Previously the relationship between mother and child had been that primal unity or uroboric state. Such function is a premise for the integration of what we take in into life, and the picture seemed to convey the message that it is necessary, at that particular time of the therapy, to pay attention to that function.

\section{Session Twenty-one}

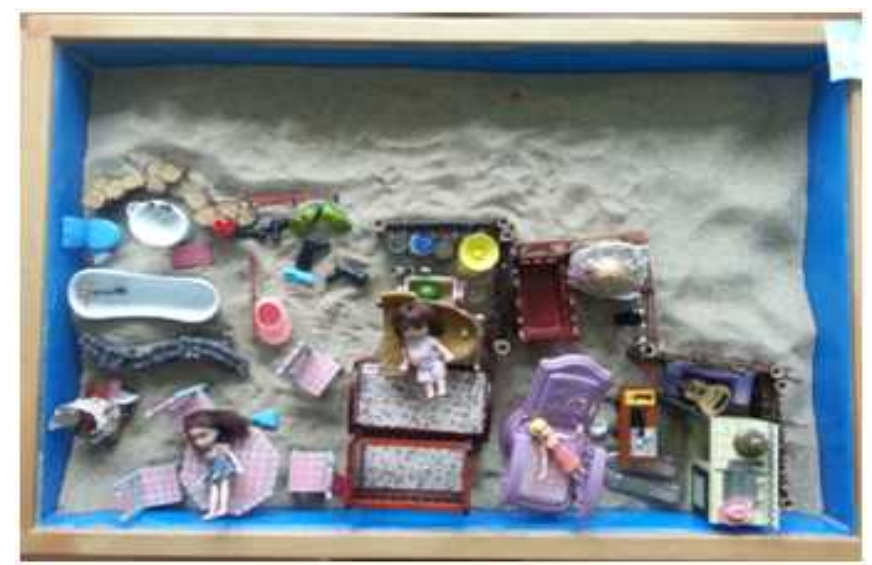

Figure 14. Sandpicture \#13

Jina made less requests of the therapist during role plays; her plays became increasingly independent. The mother reported that while Jina and her friends still fight, they now make up quickly. Moreover, Jina would not come looking for the mother to whine or cry as often as she did before, and so the mother was able to concentrate on her work at school. 
The mother added that perhaps her getting a job at a different school would be better for Jina. I felt that the mother had come to recognize what was actually needed for her child's development.

Observing how the plays of different sessions were all connected to each other, I was able to know that Jina was concentrating on her psychological-emotional flow, beyond the boundaries of time. I was able to feel an internal creative energy that continuously expresses even the smallest moments of transformation. Also, the hospital-play increasingly contained developmental aspects. Previously, Jina had forbidden the patient figure from going out of the hospital. But in this session the patient figure was allowed to roam freely around outside the hospital with her shoes on. There were changes in the play in terms of the treatments given as well. Whereas the treatments were rather long in past sessions as the patient had to receive, for instance, a surgery, only a simple checkup was done in this session. And a new figure-the chef-provided food. It looked as if the patient's teeth had healed and were able to chew food properly. Jina's development would further be facilitated by this healing.

Other new figures, a sewing machine and a guitar, are symbols of reorganization, integration, and attunement, which led me to assume that the Self-ego was being rebalanced.

\section{Session Twenty-two}

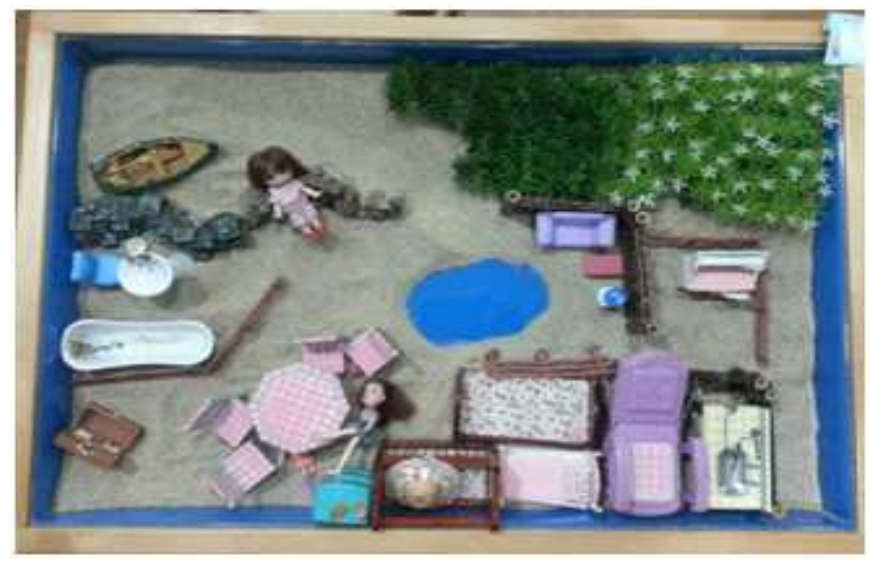

Figure 15. Sandpicture \#14 
Journal of Symbols \& Sandplay Therapy, Vol.8 No.1.

This was the last picture that the girl created in her sandplay process. The center area of the sandtray can be considered as the core of Jina's psyche and the center of the Self. The act of centralization or main focus at the center of the sandtray is very important as it is related to the Self archetype (Turner, 2005). The pond at the center of the tray is a sacred place through which Jina is able to connect to her unconscious. A sacred place facilitates the process of entering into sacred time. Eliade (1990) defined the "center" as anywhere sacredness emerges. Then it can be said that sandplay therapy is a space where sacredness is manifested. In fact, Jina's attempts to carefully push sand away to create a pond with the tray's blue bottom at the center area reminded me of a sacred ritual. I also felt that her concentration towards the center is connected to movements in her psyche.

The sandpicture does not form a perfect shape of a mandala, but it does seem to foretell a conjunction in the near future. Ideally Jina would overcome the negative mother archetype and attain wholeness through the differentiation of consciousness and the unconscious, while there is a connection or axis between them. The struggles of Jina, who is now no longer afraid to break away from the dark shadows of the mother and descend into the unconscious, will serve as energy for a positive development.

It was interesting to see the patient figure wearing a pair of shoes in this last picture, because she had been mostly barefooted and was allowed to wear shoes only when going outside. Red, the color of the shoes, symbolizes an energy of taking immediate action in life (Ammann, 2001). The red shoes appeared to be Jina's determination to step forward into the outer world by overcoming the negative mother archetype and attaining independence and autonomy. The red shoes that this figure is wearing, just like Dorothy's red shoes in the Wizard of $\mathrm{Oz}$, will take Jina to a different world to a sense of empowerment and independence, after the tornado/chaos has upset her life. Reports by the mother testified that Jina was increasingly able to express her opinions at home and was able to do many things alone. As for her relationship with her brother, whom she had greatly depended on, they would sometimes engage in fights and conflicts and sometimes engage in discussions for cooperation.

Now that the child patient figure had gotten better and no longer required surgery, 
she may leave at any time she pleases. The place to which she travels may be the sea, an external world of the unknown, sometimes chaotic or threatening, or the pond, a deep internal world. Whichever one it may be, a wooden boat is there for the girl's journey. I felt that this boat for one was good enough for Jina's journey in search of herself.

The mother reported that before therapy, she had felt distressed whenever her child played alone. But when she let go of her anxiety and saw Jina as who she is, she realized that Jina was neither sad nor angry about the situation. The negative mother archetype had blocked Jina from entering the world of experiences by tying her up in the mother's unconscious. But now Jina is psychologically separated from the mother, as clearly indicated in the picture in the form of fences, boundaries between the inner and outer worlds with access to both, we see that she is ready to leave aboard the wooden boat. Looking at her leaning against the stone wall, I had a feeling that she was looking back at the inner world as a place where she had done much work and attained development. Recognizing that as I spent time with this case, I felt deeply moved. As well, as I looked at the possibility of Jina's future journey, I felt a sense of awe and delight.

\section{Conclusion and Discussion}

This case shows how the overprotective negative mother archetype activated in the personal mother and in Jina herself tries to maintain the uroboric mother-child psychological state. Unlike what happens in typical development, in this client separation from the mother-child unity stage had not occurred because of the mother's childhood trauma and her over-protectiveness of her daughter. Jina's and her mother's unconscious and consciousness thus did not have a boundary, thus providing the opportunity for the continuation of the psychological unity of the mother and the child. Even after the primary development of consciousness, the potential for further ego-development was still impeded.

In the early stages of therapy, I felt that Jina's defensive and oppressive attitude was projected onto me as she continued her attempt to protect herself, as she did from her mother's unconscious. As my part of the co-transference was activated, I too felt distanced and 
Journal of Symbols \& Sandplay Therapy, Vol.8 No.1.

a bit defensive. However, I also understood the importance of maintaining a safe and protective space within the therapy room and assuming an attitude of containment and being present for Jina. If $I$ as the therapist was not able to deal with transference and countertransference effectively and was instead overwhelmed by the dynamics, Jina would have had found it difficult to stay in the therapy room and reorganize her psychic world. Obviously, Jina's psychic state had affected the way she communicated with people in the outer world, and this was probably why she had failed to establish deep and empathetic relationships with other people. As therapy progressed, I was sensitively attuned to positive changes in Jina's emotions, an indication of healing. By the end of our time together, she was able to develop a sense of self-awareness, express her emotions, therapeutically deal with moments of transference and countertransference. The aggressive response that Jina showed during the first therapy session transferred to the therapist in a way that made the therapist feel the moment as cold emotion. As the therapist recognized the moment, she (I) sensitively contained the deep emotion of Jina, and empathized with her unconscious emptiness and deficiency hidden under the defensive and aggressive response. I felt grateful that I could maintain an empathetic state at a deep level. Transference had occurred beyond time and space, and, as I wrote this paper even after the therapy's termination, I had the extraordinary experience of co-transference with regard to Jina's emotions through her sandpictures.

Allan Schore (2012) said that emotional empathy, a capacity of the right brain, is an indicator of an effective psychotherapy outcome, whereas an absence of perceived empathy (by Jina) has the effect of a poor psychotherapy outcome.

Being present for Jina and accepting and containing her emotions as they were, I feel that I as the therapist enabled her to accept the therapy room as a safe base for her psyche, as a sacred place, as can be inferred from her statement: "I like coming here, even if I don't really do anything significant." No doubt, she felt that play was not significant, not an unusual assumption for Korean children who are pressured by their parents to spend most of their time on their academic studies.

As sandplay therapy progressed, Jina gradually began to engage in her everyday outer life and function normally. Jina's mother increasingly became less overprotective and more 
containing and accepting. Jina also began to talk less to herself, refrained from walking around the school during class time and displayed less aggressive behaviors towards her peers. Although I cannot identify precisely where the starting point was, there seemed to be a change into a positive, mutual relationship. I felt that being separated from the state of mother-child unity and becoming independent was a scary and difficult experience for both the mother and Jina. Jina's courage in being able to struggle against the fear and ultimately obtaining independence made me feel awe once again of the child developmental process, Erich Neumann (1973) explained that the child, who is initially in a primal unity with the mother, gradually becomes separated from the mother and enters into the world of the father. As is evidenced in this case, sandplay therapy provided an environment which enabled the reconstitution of Jina's problematic primal relationship, constellation of the Self so that she developed a sense of self-worth and competency, and the reconstruction of her damaged ego-Self axis.

\section{References}

Ackroyd, E. (1993). A dictionary of dream symbols: With an introduction to dream psychology. New York: Sterling Publishing. (Trans. into Korean in 1997)

Ammann, R. (2001). Das sandspiel: Der Schöpherischeweg der Persönlichkeitsentwicklung, Dusseldorf:

Walter. (Trans. into Korean in 2009)

Birkhauser-OERI, S. (1988). The Mother: Archetypal image in fairy tales. Toronto: Inner City Books.

Cooper, J. C. (1978). An illustrated encyclopedia of traditional symbols. New York: Thames \& Hudson. (Trans. into Korean in 1994)

Dalziel, B. (2005). Grass as symbol. Unpublished symbol paper.

Edinger, E. F. (1972). Ego \& archetype. Boston: Shambhala.

Eliade, M. (1990). Image and symbol: Studies in religious symbolism. (P. Mariet, Trans.). Princeton,

NJ: Princeton University Press. (Original work published 1952)

Jang, M. K. (2017). Analytical psychological sandplay therapy. Seoul: Hakjisa.. 
Journal of Symbols \& Sandplay Therapy, Vol.8 No.1.

Jung, C. G. (1984). Archetyp und Unbewustes. Princeton: Bollingen/Princeton University Press. (Trans. into Korean in 2002)

Kalff, D. M. (1989). Sandplay. Boston: Soigo. (Trans. into Korean in 2012)

Kalsched, D. (2013). Trauma and the soul. New York: Routledge.

Lee, Y. J. (2013). A study of the sandplay therapy case of a 9-year-old girl seen from Mahler's ego developmental viewpoint. Journal of Symbols \& Sandplay Therapy, 4(1), 21-34. Leonard, L. S. (1995). Creation's heartbeat. New York: Bantam Books.

Neumann, E. (1973). Die Grosse Mutter. Dusseldorf: Walter. (Trans. into Korean in 2007)

Neumann, E. (2004). Ursprungsgeschichte des Bewusstseins. Dusseldorf: Walter. (Trans. into Korean in 2007)

Schore, A. N. (2012). The science of the art of psychotherapy. New York: Norton \& Company Inc. Steinhardt, L. (2000). Foundation and form in Jungian sandplay. New York: Jessica Kingsley Publisher Ltd. (Trans. into Korean in 2010)

Tresidder, J. (2000). Symbols and their meanings. New York: Duncan Baird Publishers Ltd. Turner, B. A. (2005). The handbook of sandplay therapy. Los Angeles, CA: Temenos Press.

Weinrib, E. L. (1983). Images of the Self. Boston: Sigo Press.

Woodman, M. (1990). The ravaged bridegroom. Toronto: Inner City Books https://en.wikipedia.org/wiki/ Pipe_dream https://ko.wikipedia.org/wiki/ http://japanesemythology.wordpress.com http://terms.naver.com/entry.nhn?docId 